GRASAS Y ACEITES 69 (1)

January-March 2018, e233

ISSN-L: 0017-3495

https://doi.org/10.3989/gya.0670171

\title{
The effect of microwave pre-treatment of rapeseed on the degradation kinetics of lipophilic bioactive compounds of the oil during storage
}

\author{
A. Rękas ${ }^{\mathrm{a}, \bigotimes}$, A. Siger ${ }^{\mathrm{b}}$ and M. Wroniak ${ }^{\mathrm{a}}$ \\ ${ }^{a}$ Faculty of Food Sciences, Department of Food Technology, Warsaw University of Life Sciences, \\ Nowoursynowska St. 159c, 02-787 Warsaw, Poland \\ ${ }^{\mathrm{b}}$ Faculty of Food Sciences and Nutrition, Department of Food Biochemistry and Analysis, \\ Poznan University of Life Sciences, Wojska Polskiego St. 28, 60- 637 Poznan, Poland \\ Corresponding author: agnieszka_rekas@sggw.pl
}

Submitted: 22 June 2017; Accepted: 11 October 2017

SUMMARY: This study examined the storage stability of tocochromanols and carotenoids in the oils prepared from microwave pre-treated (MV) rapeseeds $(2-10 \mathrm{~min}, 800 \mathrm{~W})$ during storage at $20^{\circ} \mathrm{C}$ for 12 months. In line with lipophilic antioxidant degradation throughout the storage period, changes in the antioxidant capacity of the oil were monitored. Microwaving significantly affected the concentration of lipophilic antioxidants in the oil. After 10 min of MV pre-treatment the highest content of total tocochromanols $(76.64 \mathrm{mg} / 100 \mathrm{~g})$ was achieved, whereas a maximum carotenoid concentration $(861.28 \mu \mathrm{g} / 100 \mathrm{~g})$ was obtained following $6 \mathrm{~min}$ seed MV pre-treatment. The degradation kinetics for the tocochromanols and carotenoids followed a zero-order kinetic model. From the kinetic analysis, it was shown that the degradation rate constant $(k)$ of both tocochromanols and carotenoids decreased with longer seed exposure to MV radiation. The kinetics of antioxidant capacity degradation during the storage of oils followed a zero-order reaction. The rate of antioxidant capacity degradation in the control oil was higher $\left(k=9.1 \times 10^{-2} \mathrm{mmol}\right.$ $\mathrm{TEAC} / \mathrm{l} / \mathrm{month})$ compared with oils prepared from MV pre-treated seeds $\left(k=6.8-8.0 \times 10^{-2} \mathrm{mmol} \mathrm{TEAC} / 1 / \mathrm{month}\right)$.

KEYWORDS: Antioxidant capacity; Carotenoids; Degradation kinetics; Microwaving; Rapeseed oil; Tocochromanols

RESUMEN: Efecto de pretratamientos con microondas a semillas de colza sobre la cinética de degradación de los compuestos bioactivos lipófilos del aceite durante el almacenamiento. En este estudio se determinó la estabilidad de tococromanoles y carotenoides de aceites preparados a partir de semillas de colza pretratadas con microondas (MV) (2-10 min, $800 \mathrm{~W}$ ) durante el almacenamiento a $20^{\circ} \mathrm{C}$ durante 12 meses. De acuerdo con la degradación de los antioxidantes lipófilos durante el periodo de almacenamiento, se monitorizó el cambio en la capacidad antioxidante del aceite. El microondas afectó significativamente a la concentración de antioxidantes lipofilícos en el aceite. Después de 10 minutos de pretratamiento con MV, se obtuvo el contenido más alto de tocromanoles totales $(76,64 \mathrm{mg} / 100 \mathrm{~g})$, mientras que se obtuvo una concentración máxima de carotenoides $(861,28 \mathrm{~g} / 100 \mathrm{~g})$ después de un pretratamiento con MV de 6 minutos. La cinética de degradación para los tococromanoles y carotenoides siguió un modelo cinético de orden cero. A partir del análisis cinético, se demostró que la constante de velocidad de degradación (k) tanto de los tococromanoles como de los carotenoides disminuía con una exposición más prolongada de las semillas a la radiación de MV. La cinética de la degradación de la capacidad antioxidante durante el almacenamiento de los aceites siguió una reacción de orden cero. La tasa de degradación de la capacidad antioxidante en el aceite testigo fue mayor $\left(\mathrm{k}=9,1 \times 10^{-2} \mathrm{mmol}\right.$ TEAC $\left./ 1 / \mathrm{mes}\right)$ en comparación con los aceites preparados a partir de semillas pretratadas con $\operatorname{MV}\left(\mathrm{k}=6,8-8,0 \times 10^{-2} \mathrm{mmol}\right.$ TEAC $\left./ 1 / \mathrm{mes}\right)$.

PALABRAS CLAVE: Aceite de colza; Capacidad antioxidante; Carotenoides; Cinética de degradacion; Microondas; Tococromanoles

ORCID ID: Rękas A https://orcid.org/0000-0001-5979-8430, Siger A https://orcid.org/0000-0002-3681-153X, Wroniak M https://orcid.org/0000-0002-8527-7185

Citation/Cómo citar este artículo: Rękas A, Siger A, Wroniak M. 2108. The effect of microwave pre-treatment of rapeseed on the degradation kinetics of lipophilic bioactive compounds of the oil during storage. Grasas Aceites 69 (1), e233. https://doi.org/10.3989/gya.0670171

Copyright: (C2018 CSIC. This is an open-access article distributed under the terms of the Creative Commons Attribution 4.0 International (CC BY 4.0) License. 


\section{INTRODUCTION}

Natural antioxidants, such as tocopherols, carotenoids, phospholipids, and flavonoids, delay or inhibit lipid oxidation at low concentrations. Antioxidants prevent the auto-oxidation of oils by giving their hydrogen to free radicals formed in the initiation and propagation stages of autoxidation. Antioxidants prevent free radical-induced cell and biological target damage by preventing the formation of radicals, scavenging them, or by promoting their decomposition. Examples of antioxidants to scavenge free radicals are tocopherols, lignans, flavonoids, and phenolic acids, ubiquinone (coenzyme Q), carotenoids, ascorbic acids and amino acid (Choe and Min, 2009).

During the roasting of oilseeds and nuts some antioxidants are lost due to their heat instability (Yoshida et al., 1999; Anjum et al., 2006; Vujasinovic et al., 2012; Cai et al., 2013). Others are formed via chemical reactions such as Maillard reaction products (Shrestha et al., 2013). The roasting of sesame seeds before oil extraction increases their sesamol content - the thermal degradation product of sesamolin, which is a more potent antioxidant than sesamolin (Lee et al., 2010). Thermal pre-treatment of rapeseed leads to the formation of canolol (4-vinylphenol) - a decarboxylation product of sinapic acid (Shrestha et al., 2013).

Rapeseed is an important crop worldwide. Crude rapeseed oil supplies comparable amounts of tocopherols to sunflower seed oil or soybean oil (Codex Alimentarius, 2013). It is rich in monounsaturated fatty acids (oleic acid) and polyunsaturated fatty acids (linoleic and $\alpha$-linolenic essential fatty acids) and low in saturated fatty acids. Because of favorable polyunsaturated fatty acid contents with a $2: 1$ ratio of linoleic vs. linolenic fatty acid it is considered as one of the healthiest oil on the edible oil market. The storage stability of phytochemicals has been studied for olive oil (Krichene et al., 2015), rice bran oil (Mezouari and Eichner, 2007) and rapeseed oil (Wroniak and Rękas, 2016).

The degradation of tocopherols, plastochromanol-8 and canolol during the long-term storage $\left(4^{\circ} \mathrm{C}\right)$ of rapeseed oil prepared from roasted seeds was investigated by Siger and Michalak (2016). Vaidya and Choe (2011b) studied the stability of tocopherols and lutein in oil extracted from roasted or unroasted mustard seeds during oil oxidation at $60^{\circ} \mathrm{C}$ in the dark. The effect of rapeseed microwave pre-treatment on the stability of phenolic compounds during accelerated storage $\left(60{ }^{\circ} \mathrm{C}\right.$, 10 weeks) was reported by Zheng et al., (2014). So far, kinetic models have been developed to evaluate phenolic compound and tocopherol degradation during the storage of olive oil (Lavelli et al.,
2006; Krichene et al., 2015). In our previous work (Rękas et al., 2017), the degradation kinetics of phenolic compounds in the rapeseed oil obtained from microwave pre-treated seeds ( $c v$. Monolit) during storage for 12 months at $20{ }^{\circ} \mathrm{C}$ were examined. The objective of this study was to determine the kinetic parameters for lipophilic antioxidants (tocochromanols and carotenoids) in rapeseed oil prepared from seeds exposed to microwave radiation for 2 to $10 \mathrm{~min}$ during storage at room temperature for 12 months.

\section{MATERIALS AND METHODS}

\subsection{Experimental material}

Seeds of the winter type rapeseed $c v$. Monolit were provided by the Plant Breeding Strzelce Ltd. Co. - IHAR Group, Poland. The seeds were harvested at optimum maturity, and did not contain any impurities or broken seeds. They were stored in paper bags under atmospheric conditions at $20 \pm 1{ }^{\circ} \mathrm{C}$. The moisture content of rapeseeds was $5.6 \%$.

\subsection{Reagents}

Analytical standards of $\alpha-, \beta-, \gamma$-, $\delta$-tocopherols $(\geq 95 \%)$ and carotenoids: lutein $(\geq 97.0 \%), \beta$-carotene ( $\geq 97.0 \%)$, (9-Z)- $\beta$-carotene $(\geq 95.0 \%)$, (13-Z)$\beta$-carotene $(\geq 95.0 \%)$ and 1,4 - dioxane were provided by Calbiochem-Merck Biosciences (Darmstadt, Germany). HPLC-grade n-hexane, methanol, ethyl acetate, 2,2-diphenyl-1-picrylhydrazyl radical (DPPH) and ( \pm )-6-hydroxy-2,5,7,8-tetramethylchroman-2-carboxylic acid (Trolox) were purchased from Sigma-Aldrich (St. Louis, MO, USA).

\subsection{Sample moisturizing}

The moisture content of seeds was determined based on a precision weighing balance, using Electronic Moisture Analyzer (Kern \& Sohn GmbH, Germany). A $5 \mathrm{~g}$ sample was dried at $115^{\circ} \mathrm{C}$ to constant mass and taken as a reference. The measurement accuracy of the analyzer was $0.05 \%$ wet basis. The seeds (batches of $500 \mathrm{~g}$ ) were sprayed with pre-calculated amount of water, mixed thoroughly, sealed in polyethylene bags and equilibrated at 4 $\pm 2{ }^{\circ} \mathrm{C}$ for $72 \mathrm{~h}$. Based on the results presented in our previous work (Rękas et al., 2017), the moisture level of seeds of $7.5 \%$ prevents the seeds from overheating during microwave pre-treatment, whereas seed moisturizing prior to cold-pressing to the moisture content of $8.5 \%$ enables the highest oil yield. For this reason, the seeds were moistened twice: to the moisture content of $7.5 \%$ prior to microwave pre-treatment and before cold-pressing to reach the required moisture content of $8.5 \%$. After $72 \mathrm{~h}$ of 
equilibration, the moisture content of the seeds was checked in order to verify whether homogeneous moisture distribution throughout the bulk of the seeds was reached.

\subsection{Pre-treatment with microwaves}

The rapeseeds were microwaved for 2, 4, 6, 8 and $10 \mathrm{~min}(2450 \mathrm{MHz}, 800 \mathrm{~W})$ following the procedure presented in an earlier work (Rękas et al., 2017).

\subsection{Oil extraction by cold-pressing}

Pressing was carried out by applying a screw press (Farmet, Czech Republic), and the temperature of the out-flowing oil was kept below $40{ }^{\circ} \mathrm{C}$. Once produced, the oil was stored at $4{ }^{\circ} \mathrm{C}$ overnight in the dark until analyzed.

\subsection{Storage conditions}

The oil samples were stored in $100-\mathrm{mL}$ amber glass bottles, with no access to light at a temperature of $20{ }^{\circ} \mathrm{C}$. In all samples, a nitrogen cushion was created by introducing an inert gas $\left(\mathrm{N}_{2}\right)$ into the headspace. The bottles were sealed with standard polypropylene threaded caps. Analyses were performed immediately after oil production ( 0 months of storage) and after 3, 6, 9 and 12 months of storage. For each oil sample, a series of three bottles was prepared. Samples were periodically withdrawn for scheduled analyses. Overall, 90 bottles were used in the study.

\subsection{Tocopherol and plastochromanol-8 determination}

To determine tocochromanols $(\alpha-, \beta-, \gamma$-, and $\delta$-tocopherol and PC-8), $200 \mathrm{mg}$ of oil were dissolved in $10 \mathrm{ml}$ of $n$-hexane and transferred to vials for further analysis. Separation was performed using a Waters HPLC system (Waters, Milford, MA, USA) coupled with a FLD detector (Waters 474), a PDA detector (Waters 2998), and a LiChrosorb Si 60 column $(250 \times 4.6 \mathrm{~mm}$, $5 \mu \mathrm{m}$, Merck Millipore, Darmstadt, Germany). The mobile phase was a mixture of $n$-hexane with 1,4-dioxane $(96: 4 \mathrm{v} / \mathrm{v})$ at a flow rate of $1.0 \mathrm{~mL} \cdot \mathrm{min}^{-1}$. The quantification of tocochromanols was conducted using data from the FLD with excitation/ emission wavelengths of $295 / 330 \mathrm{~nm}$, respectively. The plastochromanol-8 content was assayed and calculated following the method described by Siger et al., (2014).

\subsection{Carotenoid determination}

In order to determine carotenoid content, samples of oils $(2 \mathrm{~g})$ were saponified using $60 \% \mathrm{KOH}$ $(2 \mathrm{~mL})$, ethanol $(20 \mathrm{~mL})$ and pyrogallol $(0.5 \mathrm{~g})$.
The saponification was carried out at ethanol boiling point temperature $\left(78^{\circ} \mathrm{C}\right)$ for 30 minutes. After saponification, unsaponifiable substances were extracted using $50 \mathrm{~mL}$ n-hexane/ethyl acetate $(90: 10 \mathrm{v} / \mathrm{v})$. The $20 \mathrm{~mL}$ mixture of unsaponifiable substances was dried using a rotary evaporator and the residue was dissolved in $2 \mathrm{~mL}$ of ethyl acetate. The identification and quantification of carotenoids were made using high performance liquid chromatography (HPLC - Waters, Milford, MA) equipped in a ODS2 C18 reversed-phase column $(4.6 \times 250$ $\mathrm{mm} ; 5 \mu \mathrm{m}$ ) (Waters, Milford, MA). A gradient program was used, combining solvent A ( $80 \%$ acetonitrile and $0,05 \%$ triethylamine) and solvent B (ethyl acetate) as follows: $100-65 \%$ A (35 min), $65-50 \%$ A $(25 \mathrm{~min}), 50-100 \%$ A $(5 \mathrm{~min})$. The flow rate was $1.0 \mathrm{~mL} \cdot \mathrm{min}^{-1}$. The injection volume was $10 \mu \mathrm{l}$ while the column temperature was maintained at $30{ }^{\circ} \mathrm{C}$. The signal was monitored at $200-600 \mathrm{~nm}$ with the diode array detector (DAD) (UV-VIS Waters, Milford, MA). The quantitative determination of carotenoids was carried out by comparing retention times and diode array spectral characteristics with corresponding standards.

\subsection{Antioxidant capacity}

The radical scavenging capacity (RSC) of the oil sample was analyzed using the DPPH radical-scavenging assay according to the method described by Tuberoso et al., (2007). The antioxidant capacity of the oil (TF), hydrophilic (HF), and lipophilic (LF) fractions were measured at $517 \mathrm{~nm}$ using Spectronic Helios $\beta$ UV-Vis spectrophotometer (Thermo Electron Corporation, Waltham, MA, USA). The results were expressed as a Trolox equivalent antioxidant capacity (TEAC, mmol/l), using a Trolox calibration curve in the range $0.02-4.00 \mathrm{mM}$.

\subsection{Kinetics of antioxidant lipophilic compounds and antioxidant capacity degradation}

The degradation of tocopherols, plastochromanol-8, carotenoids and antioxidant capacity in rapeseed oils produced from microwave pre-treated seeds was calculated according to the standard equation from the zero-order reaction model. The degradation rate constant was determined by fitting Eq. (1) to the experimental data.

$$
C_{t}=C_{0}+k t
$$

Where $C_{t}$ is the studied compound concentration $(\alpha-, \beta-, \gamma-, \delta$-tocopherols, plastochromanol-8, lutein, $\beta$-carotene, 9-Z- $\beta$-carotene, $13-Z$ - $\beta$-carotene, antioxidant capacity of the oil (TF) and its lipophilic (LF), hydrophilic (HF) fraction) after $t$ months of storage, $C_{0}$ is the initial 
concentration of the studied compounds, $k$ is the kinetic rate constant.

\subsection{Statistical analysis}

Data are expressed as Mean \pm SD. To examine the effect of microwave pre-treatment of rapeseeds on the crude oil variables studied, one-way ANOVA was used when the variables fulfilled parametric conditions, and the Kruskal-Wallis test when they were nonparametric. Significance was established at a probability of $p<0.05$, using Statistica 12.0 software (StatSoft, Inc., Tulsa, OK).

\section{RESULTS AND DISCUSSION}

\subsection{Tocopherols}

The initial contents of the individual tocopherol homologues in the analyzed oil samples are given in Table 1. The main components of the control oil sample were $\gamma$ - and $\alpha$-tocopherol $(\gamma$ - and $\alpha$-T) with the concentration of 31.19 and $27.36 \mathrm{mg} \cdot 100 \mathrm{~g}^{-1}$, respectively, followed by plastochromanol-8 (PC8), present at a concentration of $2.26 \mathrm{mg} \cdot 100 \mathrm{~g}^{-1}$; whereas the sum of $\delta$ - and $\beta$-tocopherol $(\delta$ - and $\beta$-T) was $1.04 \%$ of the total tocochromanols. In the oils produced from MV pre-treated seeds, the level of total tocochromanols ranged from 60.84 to 76.64 $\mathrm{mg} \cdot 100 \mathrm{~g}^{-1}$. Similarly to the results presented by other authors (Yoshida et al., 1999; Anjum et al., 2006) the reduction in $\alpha$-T content with longer seed exposure to microwaves was observed. The amounts of $\gamma$-T increased with increasing MV time, the highest level of $\gamma$-T was found in the oil prepared from $10 \mathrm{~min}$ MV seeds $\left(45.14 \mathrm{mg} \cdot 100 \mathrm{~g}^{-1}\right)$. An increase in $\gamma$-T was also found in the oils pressed from roasted rapeseeds (Siger et al., 2015) and pumpkin seeds (Vujasinoviet al., 2012); whereas the roasting of pine nuts (Cai et al., 2013) and sunflower seeds (Anjum et al., 2006) resulted in a significant reduction in the $\gamma$-T concentration in the oil. $\beta$-T was almost unchanged by MV pre-treatment applications, while $\delta$-T first increased and then decreased, depending on the time of seed exposure to MV radiation. The behavior of tocopherol homologues during thermal seed pre-treatment differed among one another due to their different thermo-stabilities. $\alpha$-T was the most thermal sensitive, followed by $\beta$-T; whereas the highest thermo-stability was shown, equally, by $\delta$ - and $\gamma$-T (Valavanidis et al., 2004). As shown by Moreau et al., (1999) a significant amount of $\gamma$-T in corn hulls formed complexes with proteins or was linked to phosphates or phospholipids. An increase in $\gamma$-T in the oil prepared from thermally pre-treated corn may be a result of heat-induced degradation of these bonds. Wijesundera et al., (2008) offered a possible explanation for the heat-induced increase in the levels of tocopherols, suggesting possible co-elution of tocopherols with other compounds formed during rapeseed roasting. Moreover, Matthäus (2012) suggested a potential role of canolol, formed during rapeseed thermal pre-treatment, in protecting the tocopherols from thermal degradation. The level

TABLE 1. Tocochromanol $\left(\mathrm{mg} \cdot 100 \mathrm{~g}^{-1}\right)$ and carotenoid $\left(\mu \mathrm{g} \cdot 100 \mathrm{~g}^{-1}\right)$ concentrations in rapeseed oil samples pressed from microwave treated seeds.

\begin{tabular}{|c|c|c|c|c|c|c|}
\hline \multirow[b]{2}{*}{ Compound } & \multicolumn{6}{|c|}{ Microwave pretreatment time (min) } \\
\hline & $\mathbf{0}$ & 2 & 4 & 6 & 8 & 10 \\
\hline \multicolumn{7}{|c|}{ Tocochromanols $\left(\mu \mathrm{g} \cdot 100 \mathrm{~g}^{-1}\right)$} \\
\hline$\alpha$-Tocopherol & $27.36 \pm 0.25^{\mathrm{b}}$ & $25.63 \pm 0.13^{\mathrm{a}}$ & $25.65 \pm 0.11^{\mathrm{a}}$ & $25.92 \pm 0.07^{\mathrm{a}}$ & $25.07 \pm 0.07^{\mathrm{a}}$ & $25.21 \pm 0.09^{\mathrm{a}}$ \\
\hline$\beta$-Tocopherol & $0.10 \pm 0.02^{\mathrm{a}}$ & $0.10 \pm 0.03^{\mathrm{a}}$ & $0.08 \pm 0.02^{\mathrm{a}}$ & $0.09 \pm 0.03^{\mathrm{a}}$ & $0.09 \pm 0.01^{\mathrm{a}}$ & $0.10 \pm 0.01^{\mathrm{a}}$ \\
\hline$\gamma$-Tocopherol & $31.19 \pm 0.08^{\mathrm{a}}$ & $31.20 \pm 0.19^{\mathrm{a}}$ & $32.79 \pm 0.06^{\mathrm{ab}}$ & $33.34 \pm 0.17^{\mathrm{b}}$ & $35.87 \pm 0.07^{\mathrm{b}}$ & $45.14 \pm 0.08^{\mathrm{c}}$ \\
\hline$\delta$-Tocopherol & $0.54 \pm 0.03^{\mathrm{c}}$ & $0.59 \pm 0.03^{\mathrm{c}}$ & $0.49 \pm 0.03^{\mathrm{b}}$ & $0.42 \pm 0.02^{\mathrm{a}}$ & $0.47 \pm 0.02^{\mathrm{b}}$ & $0.44 \pm 0.01^{\mathrm{a}}$ \\
\hline PC-8 & $2.26 \pm 0.14^{\mathrm{a}}$ & $3.31 \pm 0.12^{\mathrm{b}}$ & $4.70 \pm 0.14^{\mathrm{c}}$ & $5.09 \pm 0.07^{\mathrm{d}}$ & $5.72 \pm 0.22^{\mathrm{e}}$ & $5.75 \pm 0.10^{\mathrm{e}}$ \\
\hline $\begin{array}{l}\text { Total } \\
\text { tocochromanols }\end{array}$ & $61.45 \pm 0.27^{\mathrm{b}}$ & $60.84 \pm 0.23^{\mathrm{a}}$ & $63.72 \pm 0.07^{\mathrm{b}}$ & $64.86 \pm 0.22^{\mathrm{b}}$ & $67.23 \pm 0.14^{\mathrm{c}}$ & $76.64 \pm 0.15^{\mathrm{d}}$ \\
\hline \multicolumn{7}{|c|}{ Carotenoids $\left(\mu \mathrm{g} \cdot 100 \mathrm{~g}^{-1}\right)$} \\
\hline Lutein & $225.90 \pm 0.55^{\mathrm{b}}$ & $222.18 \pm 0.58^{\mathrm{a}}$ & $574.49 \pm 0.99^{\mathrm{e}}$ & $545.03 \pm 1.77^{\mathrm{d}}$ & $441.03 \pm 0.22^{\mathrm{c}}$ & $442.70 \pm 0.82^{\mathrm{c}}$ \\
\hline$\beta$-Carotene & $115.01 \pm 0.31^{\mathrm{a}}$ & $116.53 \pm 0.5^{\mathrm{a}}$ & $171.52 \pm 1.13^{\mathrm{c}}$ & $219.06 \pm 0.59^{\mathrm{d}}$ & $157.89 \pm 0.76^{\mathrm{b}}$ & $172.94 \pm 0.71^{\mathrm{c}}$ \\
\hline 9-Z- $\beta$-Carotene & $45.00 \pm 0.05^{\mathrm{c}}$ & $41.52 \pm 0.46^{\mathrm{b}}$ & $40.58 \pm 0.44^{\mathrm{b}}$ & $66.40 \pm 0.15^{\mathrm{d}}$ & $35.81 \pm 0.60^{\mathrm{a}}$ & $37.99 \pm 0.22^{\mathrm{a}}$ \\
\hline 13 -Z- $\beta$-Carotene & $20.51 \pm 0.14^{\mathrm{c}}$ & $17.69 \pm 0.29^{\mathrm{b}}$ & $22.46 \pm 0.25^{\mathrm{c}}$ & $30.79 \pm 0.23^{\mathrm{d}}$ & $18.61 \pm 0.28^{\mathrm{b}}$ & $15.58 \pm 0.40^{\mathrm{a}}$ \\
\hline $\begin{array}{l}\text { Total } \\
\text { carotenoids }\end{array}$ & $406.42 \pm 0.15^{\mathrm{b}}$ & $397.92 \pm 1.74^{\mathrm{a}}$ & $809.04 \pm 2.31^{\mathrm{e}}$ & $861.28 \pm 1.10^{\mathrm{f}}$ & $653.34 \pm 0.66^{\mathrm{c}}$ & $669.21 \pm 2.16^{\mathrm{d}}$ \\
\hline
\end{tabular}

Means in a row (a-e across microwaving time) followed by the same letter are not significantly different $(p<0.05)$. 
of PC-8 in the oils prepared from MV seeds varied

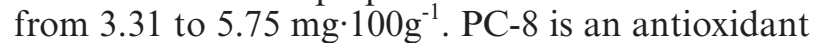
that, together with tocopherols and tocotrienols, belongs to the group of tocochromanols. Recently, its antioxidant capacity has been documented to be similar to that of $\gamma$-tocotrienol and 1.5 times higher than of $\alpha$-tocopherol (Siger et al., 2014). According to Shrestha and De Meulenaer (2014) it is possible that a thermally-induced disruption of the internal structure of rapeseeds during roasting causes increased extractability of PC-8 from the seeds.

After 12 months of storage, the level of total tocochromanols in the control oil decreased from 61.45 to $43.67 \mathrm{mg} \cdot 100 \mathrm{~g}^{-1}(28.9 \%$ loss $)$ (Table 2$)$. Throughout the entire storage period, $33.4 \%$ of $\gamma-\mathrm{T}, 27.4 \%$ of $\alpha-\mathrm{T}, 25.0 \%$ of $\delta$-T and PC-8 degraded (Fig. 1a-c); whereas $\beta$-T was undetectable after 9 months of storage (data not shown). The results presented by Wroniak and Rękas (2016) showed 59.7 and $84.3 \%$ loss in $\gamma$ - and $\alpha$-T after 12 months of storage of cold-rapeseed oil in the dark at room temperature. The storage of olive oil in closed glass bottles at room temperature for 9 months resulted in the degradation of $80.90 \% \alpha-\mathrm{T}$ (SamaniegoSánchez et al., 2012). In crude rice bran oil after 240 days of storage $\left(20^{\circ} \mathrm{C}\right.$, in the dark) the total tocopherol level decreased by about $72 \%$ (Mezouari and Eichner, 2007).

During 12 months' storage of the oils, the total amount of tocochromanols decreased by 26.0, 23.2, $23.0,23.5$ and $22.1 \%$, respectively, for oils pressed from seeds MV for 2, 4, 6, 8 and $10 \mathrm{~min}$. (Table 2). The percentage loss in individual tocopherol homologues and PC-8 was dependent on the seeds' MV pre-treatment time (Fig. 1a-c). After 12 months of storage, the level of $\alpha$-T was reduced by $24.5,20.4$,
$21.2,18.8$ and $17.6 \%$, in the oils pressed from seed MV for 2 to $10 \mathrm{~min}$, respectively. For PC-8, the highest reduction $(54.6 \%)$ was observed in the oil pressed from 2 min MV seeds, while 4 and 10 min seeds exposure to MV resulted in the lowest loss in PC-8 (17.2 and $18.2 \%$, respectively) in the oil. The losses in $\gamma$-T in the oils prepared from MV seeds were comparable to that of the control oil ( $25 \%$ loss), and were within the range of $23.6-24.3 \%$. Unlike other tocopherol homologues, after 12 months of storage, a decrease in $\delta$-T in the oils pressed from MV seeds was, in most cases, higher than that observed in the control oil (27.4\%), and ranged from 18.4 to $41.5 \%$. After 3 months of storage, $\beta$-T was undetectable in the oils produced from seed MV for 6-10 min, and was reduced to zero in all the oil samples after a storage period of 9 months (data not shown). Similarly to our results, a higher storage stability of tocopherols was reported by Vaidya and Choe (2011a), who investigated the effect of mustard seed roasting (160 ${ }^{\circ} \mathrm{C}$ ) on the stability of tocopherols during oil oxidation at $60^{\circ} \mathrm{C}$ in the dark for 12 days.

The linear relationship between tocochromanol contents in the analyzed rapeseed oil and storage period followed zero-order kinetics (Eq. 1). The estimated values of the determination coefficients $\left(R^{2}\right)$ and the degradation rate constants $(k)$ for the oils prepared from the control and MV seeds are presented in Table 3 . The degradation rate constant of individual tocochromanols varied significantly, depending on the tocopherol homologue. As shown in Table 3, $k$ values obtained for $\alpha$-T decreased with longer seed MV pre-treatment time (0.763-0.369 $\mathrm{mg} / 100 \mathrm{~g} / \mathrm{month})$, longer seed MV resulted in a higher degradation rate of $\gamma-\mathrm{T}(0.631-0.935 \mathrm{mg} / 100 \mathrm{~g} /$ month), whereas the degradation of $\delta$-T was almost

TABLE 2. Tocochromanol $\left(\mathrm{mg} \cdot 100 \mathrm{~g}^{-1}\right)$ and carotenoid $\left(\mu \mathrm{g} \cdot 100 \mathrm{~g}^{-1}\right)$ concentrations in rapeseed oil samples pressed from microwave treated seeds.

\begin{tabular}{|c|c|c|c|c|c|c|}
\hline \multirow{2}{*}{$\begin{array}{l}\text { Storage period } \\
\text { (months) }\end{array}$} & \multicolumn{6}{|c|}{ Microwave pre-treatment time (min) } \\
\hline & $\mathbf{0}$ & 2 & 4 & 6 & 8 & 10 \\
\hline \multicolumn{7}{|c|}{ Total tocochromanols $\left(\mu \mathrm{g} \cdot 100 \mathrm{~g}^{-1}\right)$} \\
\hline 0 & $61.45 \pm 0.41^{\mathrm{c}}$ & $60.84 \pm 0.35^{\mathrm{c}}$ & $63.40 \pm 0.15^{\mathrm{c}}$ & $64.71 \pm 0.29^{\mathrm{c}}$ & $66.23 \pm 0.17^{\mathrm{c}}$ & $70.64 \pm 0.08^{\mathrm{c}}$ \\
\hline 3 & $55.95 \pm 0.14^{\mathrm{b}}$ & $58.50 \pm 0.16^{\mathrm{b}}$ & $60.38 \pm 0.34^{\mathrm{bc}}$ & $60.49 \pm 0.30^{\mathrm{c}}$ & $60.73 \pm 0.32^{\mathrm{bc}}$ & $71.30 \pm 0.26^{\circ}$ \\
\hline 6 & $54.12 \pm 0.12^{\mathrm{b}}$ & $54.91 \pm 0.22^{\mathrm{b}}$ & $59.21 \pm 0.38^{\mathrm{b}}$ & $57.35 \pm 0.22^{\mathrm{b}}$ & $58.25 \pm 0.26^{\mathrm{b}}$ & $68.19 \pm 0.36^{\mathrm{b}}$ \\
\hline 9 & $47.89 \pm 0.24^{\mathrm{a}}$ & $49.19 \pm 0.18^{\mathrm{a}}$ & $53.36 \pm 0.34^{\mathrm{ab}}$ & $54.44 \pm 0.15^{\mathrm{b}}$ & $56.32 \pm 0.37^{\mathrm{b}}$ & $64.70 \pm 0.28^{\mathrm{b}}$ \\
\hline 12 & $43.67 \pm 0.40^{\mathrm{a}}$ & $45.03 \pm 0.20^{\mathrm{a}}$ & $48.91 \pm 0.12^{\mathrm{a}}$ & $49.95 \pm 0.14^{\mathrm{a}}$ & $51.46 \pm 0.22^{\mathrm{a}}$ & $59.58 \pm 0.16^{\mathrm{a}}$ \\
\hline \multicolumn{7}{|c|}{ Total carotenoids $\left(\mu \mathrm{g} \cdot 100 \mathrm{~g}^{-1}\right)$} \\
\hline 0 & $406.42 \pm 0.15^{\mathrm{e}}$ & $397.92 \pm 1.74^{\mathrm{e}}$ & $809.04 \pm 2.31^{\mathrm{e}}$ & $861.28 \pm 1.10^{\mathrm{e}}$ & $653.34 \pm 0.66^{\mathrm{e}}$ & $669.21 \pm 2.16^{\mathrm{e}}$ \\
\hline 3 & $367.73 \pm 1.49^{\mathrm{d}}$ & $364.74 \pm 0.91^{\mathrm{d}}$ & $738.94 \pm 5.00^{\mathrm{d}}$ & $797.86 \pm 5.91^{\mathrm{d}}$ & $624.65 \pm 14.67^{\mathrm{d}}$ & $579.40 \pm 5.59^{\mathrm{d}}$ \\
\hline 6 & $317.75 \pm 2.54^{\mathrm{c}}$ & $300.25 \pm 2.58^{\mathrm{c}}$ & $632.25 \pm 6.20^{\mathrm{c}}$ & $670.97 \pm 4.64^{\mathrm{c}}$ & $574.86 \pm 2.27^{\mathrm{c}}$ & $533.23 \pm 4.42^{\circ}$ \\
\hline 9 & $243.60 \pm 0.71^{b}$ & $231.58 \pm 0.69^{b}$ & $522.02 \pm 3.81^{\mathrm{b}}$ & $542.15 \pm 6.45^{\mathrm{b}}$ & $535.02 \pm 6.05^{\mathrm{b}}$ & $455.54 \pm 2.41^{b}$ \\
\hline 12 & $207.77 \pm 0.64^{\mathrm{a}}$ & $198.62 \pm 0.98^{\mathrm{a}}$ & $446.32 \pm 1.01^{\mathrm{a}}$ & $477.62 \pm 1.89^{\mathrm{a}}$ & $513.67 \pm 3.86^{\mathrm{a}}$ & $385.02 \pm 4.03^{\mathrm{a}}$ \\
\hline
\end{tabular}

Means in a column (a-e across storage period) followed by the same letter are not significantly different $(p<0.05)$. 
(a)

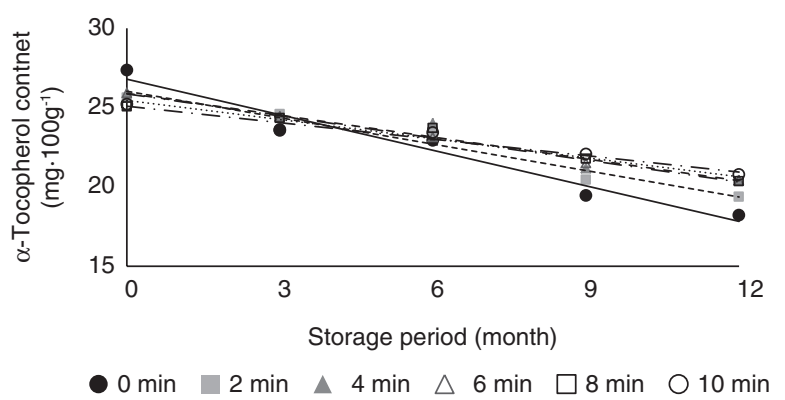

(b)

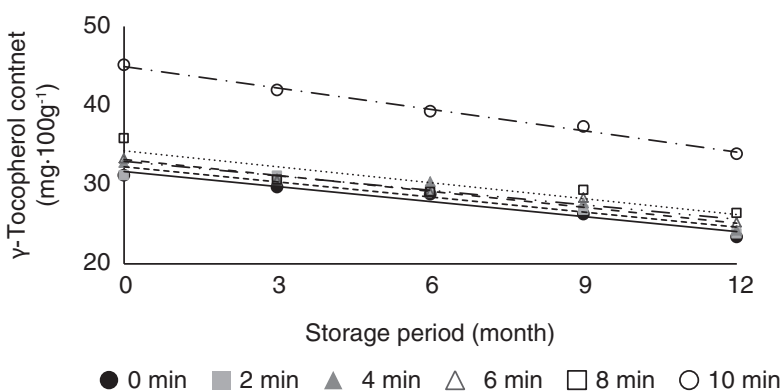

(c)

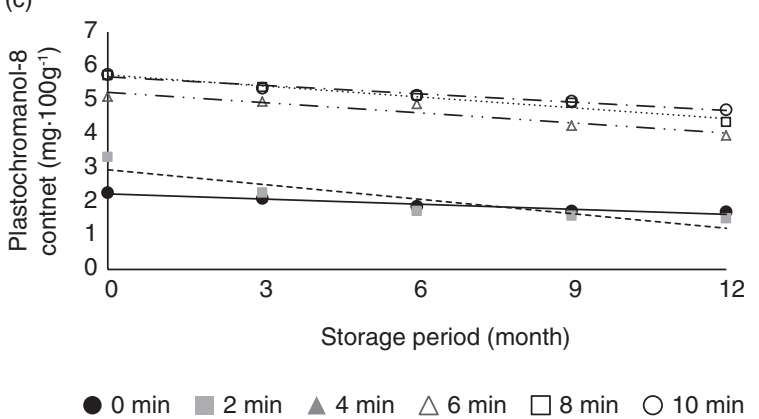

FIGURE 1. Concentrations of $\alpha$ - and $\gamma$-tocopherol and plastochromanol- $8\left(\mathrm{mg} \cdot 100 \mathrm{~g}^{-1}\right)$ in rapeseed oil samples pressed from microwave-treated seeds stored at $20^{\circ} \mathrm{C}$ in the dark for 12 months.

unchanged by the seed thermal pre-treatment prior to oil cold-pressing. The $k$ values of PC-8 showed that the degradation of this compound proceeded at a faster rate in the oil samples pressed from MV seeds than in the control oil. Overall, the degradation rate of total tocochromanols in the oils prepared from MV seeds was slightly lower than that of the control oil $(k=1.482 \mathrm{mg} / 100 \mathrm{~g} / \mathrm{month})$, with $k$ values of $1.317,1.234,1.243,1.314$ and 1.412 , for seed pre-treatment for 2-10 min, respectively. In a study of virgin olive oil storage for 18 months at temperatures of $5-50{ }^{\circ} \mathrm{C}$, the degradation of $\alpha$-T was found to follow zero-order kinetics (Krichene et al. 2015). Lavelli et al., (2006), concluded that a pseudo first-order kinetic model was suitable to describe the reduction in $\alpha$-T in the extra virgin olive oil stored for 8 months $\left(25\right.$ and $\left.40{ }^{\circ} \mathrm{C}\right)$.

\subsection{Carotenoids}

The effect of rapeseed MV pre-treatment on the concentration of carotenoids in presented in Table 1 . A total of 4 carotenoids (lutein, $\beta$-carotene, 9-Z- $\beta$-carotene and 13-Z- $\beta$-carotene) were detected in the control rapeseed oil. Lutein was the predominant carotenoid $(225.90 \mu \mathrm{g} / 100 \mathrm{~g})$, followed by $\beta$-carotene $\left(115.01 \mu \mathrm{g} \cdot 100 \mathrm{~g}^{-1}\right)$ and its isomers, 9-Z- $\beta$ - and 13-Z- $\beta$-carotene, were present at a concentration of 45.00 and $20.51 \mu \mathrm{g} \cdot 100 \mathrm{~g}^{-1}$, respectively. Total and individual carotenoid contents in the oil were significantly $(\mathrm{p}<0.05)$ altered by the seed MV pre-treatment (Table 1). The highest level of total carotenoids in the oils prepared from MV-treated seeds was achieved after seed exposure to MV for 4 and $6 \mathrm{~min}(809.04$ and $861.28 \mu \mathrm{g} / 100 \mathrm{~g}$, respectively). At first, the total carotenoid contents in the oil decreased by $2.1 \%$ after 2 -min seed MV, and then increased by $99.1,111.9,62.6$ and $64.7 \%$, after seed MV pre-treatment for 4-10 min, respectively. As suggested by Vaidya and Choe (2011a), increased carotenoid contents in oils produced from heated seeds may be partially explained by the fact that carotenoids are bound to proteins and form thermo-stable carotenoid-protein complexes. A thermally induced process of destruction of the internal seed cell structure, including protein denaturation, increases the oil's accessibility to lipidsoluble carotenoids. The highest concentration of lutein in the oil was achieved after 4 min seed MV $\left(574.49 \mu \mathrm{g} \cdot 100 \mathrm{~g}^{-1}\right), 6$-min seed exposure to MV was found to cause the highest increase in $\beta$-carotene contents in the oil $\left(219.06 \mu \mathrm{g} \cdot 100 \mathrm{~g}^{-1}\right)$. Thermal degradation leads to $\beta$-carotene oxidation, the first step comprises its conversion to Z-isomers. The behavior of $\beta$-carotene in the oil oxidation process depends on its concentration and on the lipid medium, exposure to light, presence or absence of other antioxidants and pro-oxidants (Zeb, 2012). Thermal degradation of all-E- $\beta$-carotene, $9-Z-\beta$ carotene, lycopene and lutein during safflower oil heating at 75,85 and $95^{\circ} \mathrm{C}$ showed degradation rates in the following order: lycopene $>$ all-E- $\beta$-carotene $\approx$ 
The effect of microwave pre-treatment of rapeseed on the degradation kinetics $\bullet 7$

TABLE 3. Kinetic parameters from zero-order reaction kinetics for the tocochromanol and carotenoid degradation during the storage of rapeseed oils pressed from microwave treated seeds.

\begin{tabular}{|c|c|c|c|c|c|c|c|c|c|c|c|}
\hline \multirow{2}{*}{$\begin{array}{l}\text { Compound } \\
\text { Parameter }\end{array}$} & & \multicolumn{2}{|c|}{$\alpha$-Tocopherol } & \multicolumn{2}{|c|}{$\gamma$-Tocopherol } & \multicolumn{2}{|c|}{$\delta$-Tocopherol } & \multicolumn{2}{|c|}{ PC-8 } & \multicolumn{2}{|c|}{$\begin{array}{c}\text { Total } \\
\text { tocochromanols }\end{array}$} \\
\hline & & $k$ & $R^{2}$ & $k$ & $R^{2}$ & $k$ & $R^{2}$ & $k$ & $R^{2}$ & $k$ & $R^{2}$ \\
\hline \multirow{6}{*}{$\begin{array}{l}\text { Microwave pre- } \\
\text { treatment time } \\
\text { (min) }\end{array}$} & $\mathbf{0}$ & 0.763 & 0.9578 & 0.651 & 0.9558 & 0.012 & 0.9172 & 0.047 & 0.9443 & 1.482 & 0.9818 \\
\hline & 2 & 0.522 & 0.9626 & 0.615 & 0.9178 & 0.021 & 0.8914 & 0.151 & 0.8160 & 1.317 & 0.9797 \\
\hline & 4 & 0.436 & 0.9418 & 0.714 & 0.9331 & 0.010 & 0.9156 & 0.067 & 0.9844 & 1.234 & 0.9568 \\
\hline & 6 & 0.459 & 0.9970 & 0.675 & 0.9560 & 0.006 & 0.9156 & 0.096 & 0.9047 & 1.243 & 0.9925 \\
\hline & 8 & 0.394 & 0.9545 & 0.789 & 0.8365 & 0.009 & 0.9156 & 0.115 & 0.9697 & 1.314 & 0.9565 \\
\hline & 10 & 0.369 & 0.9631 & 0.935 & 0.9932 & 0.012 & 0.9156 & 0.087 & 0.9730 & 1.412 & 0.9912 \\
\hline \multirow{2}{*}{$\begin{array}{l}\text { Compound } \\
\text { Parameter }\end{array}$} & & \multicolumn{2}{|c|}{ Lutein } & \multicolumn{2}{|c|}{$\beta$-Carotene } & \multicolumn{2}{|c|}{ 9-Z- $\beta$-Carotene } & \multicolumn{2}{|c|}{ 13-Z- $\beta$-Carotene } & \multicolumn{2}{|c|}{ Total carotenoids } \\
\hline & & $k$ & $R^{2}$ & $k$ & $R^{2}$ & $k$ & $R^{2}$ & $k$ & $R^{2}$ & $k$ & $R^{2}$ \\
\hline \multirow{6}{*}{$\begin{array}{l}\text { Microwave } \\
\text { pre-treatment } \\
\text { time (min) }\end{array}$} & $\mathbf{0}$ & 8.576 & 0.9833 & 5.487 & 0.9848 & 2.152 & 0.9690 & 0.340 & 0.9788 & 16.555 & 0.9872 \\
\hline & 2 & 8.519 & 0.9720 & 5.777 & 0.9725 & 1.876 & 0.9714 & 0.435 & 0.9705 & 16.608 & 0.9843 \\
\hline & 4 & 20.113 & 0.9942 & 8.173 & 0.9908 & 1.615 & 0.9988 & 0.326 & 0.4892 & 30.227 & 0.9942 \\
\hline & 6 & 15.767 & 0.9737 & 11.816 & 0.9551 & 3.748 & 0.9717 & 0.640 & 0.8388 & 31.971 & 0.9846 \\
\hline & 8 & 4.335 & 0.9856 & 5.922 & 0.9949 & 1.015 & 0.6671 & 0.367 & 0.5590 & 11.639 & 0.9850 \\
\hline & 10 & 12.088 & 0.9931 & 9.330 & 0.9669 & 1.854 & 0.9613 & 0.410 & 0.9826 & 23.682 & 0.9933 \\
\hline
\end{tabular}

$k$ - kinetic rate constant (mg/100g/month, for tocochromanols; $\mu \mathrm{g} / 100 \mathrm{~g} / \mathrm{month}$, for carotenoids); $R^{2}$ - coefficient of determination

9-Z- $\beta$-carotene > lutein (Henry et al., 1998). In a study of heat-induced degradation of carotenoids in crude paprika oleoresins diluted with high oleic or high linolenic oil, the conversion $\mathrm{E}$ to $\mathrm{Z}$ isomers was initially higher than the degradation of Z-isomers (Pérez-Gálvez and Mínguez-Mosquera, 2004). In our study, the degradation of $\beta$-carotene $Z$-isomers was observed after $8 \mathrm{~min}$ of MV seeds pre-treatment. Achir et al., (2010) found all E-lutein to be more resistant to degradation than all E- $\beta$-carotene during palm olein and Vegetaline heating at 120-180 ${ }^{\circ} \mathrm{C}$. Achir et al., (2011) stated that 9-Z- $\beta$-carotene could be a good degradation indicator during oil storage or processing.

The levels of total and individual carotenoids in the control oil were significantly reduced $(\mathrm{p}<0.05)$ during storage for 12 months (Table 2, Fig. 2). After the entire storage period, total carotenoid concentration was reduced by $48.9^{\circ} \%$ (a decrease from 406.42 to $\left.207.77 \mu \mathrm{g} \cdot 100 \mathrm{~g}^{-1}\right)$. In this oil, $\beta$-carotene and 9-Z- $\beta$ carotene showed the greatest losses of 57.2 and $57.4 \%$, respectively. The respective losses in lutein and 13-Z-B-carotene were 45.6 and $19.9 \%$ (Fig. 2).

During 12 months of storage, a decrease in lutein in the oils pressed from MV pre-treated seeds was lower than in the control oil; while the percentage loss in $\beta$-carotene and its isomers exceeded that observed in the control oil (Fig. 2a,b). The only exception was the oil prepared from seed MV for $8 \mathrm{~min}$, in which the lowest reduction in individual carotenoids was found. In this oil, after a storage period of 12 months, the amounts of lutein, $\beta$ - carotene and 9-Z- $\beta$-carotene decreased by 11.8 , 45.0 and $46.7 \%$, respectively. Vaidya and Choe $(2011 \mathrm{a}, \mathrm{b})$ found that the increased thermo-oxidative stability of mustard oil prepared from roasted seeds was highly correlated with improved heat stabilities for both tocopherols and lutein.

When the total carotenoid retention of rapeseed oil was plotted against storage period, $R^{2}$ was higher than 0.98 , thus a decrease in carotenoids followed zero-order reaction kinetics (Eq. 1). The $k$ values of lutein, $\beta$-, 9-Z- $\beta$ - and 13-Z- $\beta$-carotene in the control oil were $8.576,5.487,2.152,0.340 \mu \mathrm{g} / 100 \mathrm{~g} / \mathrm{month}$, respectively. As can be seen from Table 3 , the degradation rate of individual carotenoids in the analyzed oil was significantly affected by the applied MV pretreatment. The loss in lutein progressed at the fastest rate in the oil pressed from 4, 6 and 10 min MV seeds $(k=20.113,15.767,12.088 \mu \mathrm{g} / 100 \mathrm{~g} / \mathrm{month}$, respectively); while after $8 \mathrm{~min}$ seed exposure to MV, the stability of lutein was the highest, as $k$ was $4.335 \mu \mathrm{g} / 100 \mathrm{~g} /$ month. The degradation rate of $\beta$-carotene in the oils from 2 and 8 min MV seeds $(k=5.777$ and 5.922 $\mu \mathrm{g} / 100 \mathrm{~g} / \mathrm{month}$, respectively) was comparable to that of the control oil $(k=5.487 \mu \mathrm{g} / 100 \mathrm{~g} / \mathrm{month})$. MV pretreatment for 4, 6 and 10 min resulted in a significant increase in $\beta$-carotene degradation when compare to the control oil. In general, the degradation of 9-Z- $\beta$ carotene in the oils pressed from heated seeds progressed at a lower rate when compare to the control oil (with the exception of oil from 6 min MV seeds); while $13-Z-\beta$-carotene loss rate was comparable to that of the control oil (Fig. 2c,d). The degradation of 

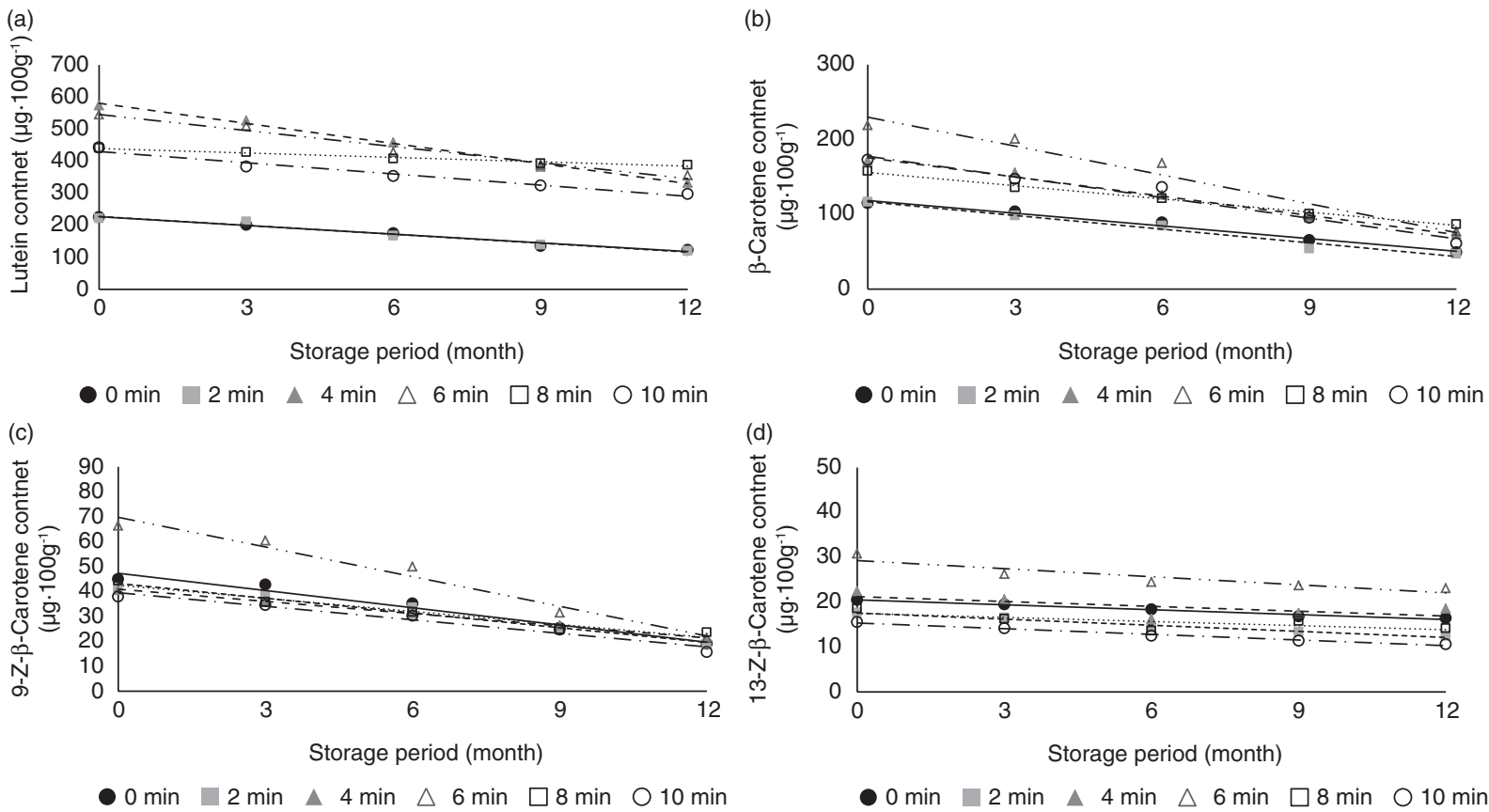

FigurE 2. Concentrations of lutein, $\beta$-carotene, $9-Z$ - $\beta$-carotene and $13-Z$ - $\beta$-carotene $\left(\mu \mathrm{g} \cdot 100 \mathrm{~g}^{-1}\right)$ in rapeseed oil samples pressed from microwave-treated seeds stored at $20{ }^{\circ} \mathrm{C}$ in the dark for 12 months.

total carotenoids in the oil obtained from $2 \mathrm{~min} \mathrm{MV}$ seeds was almost the same as in the control oil $(k=$ 16.608 and $16.555 \mu \mathrm{g} / 100 \mathrm{~g} / \mathrm{month}$, respectively). The slowest degradation rate of total carotenoids over the entire storage period was noted for the oil pressed from $8 \mathrm{~min}$ MV seeds $(k=11.639 \mu \mathrm{g} / 100 \mathrm{~g} / \mathrm{month})$; while the highest loss rate was found after 4,6 and 10 min seed exposure to heat pre-treatment $(k=30.227$, 31.971 and $23.682 \mu \mathrm{g} / 100 \mathrm{~g} / \mathrm{month}$, respectively).

\subsection{Antioxidant capacity}

The results of the antioxidant capacity measured for the oil (TF) and its hydrophilic (HF) and lipophilic (LF) fractions are reported in Table 4 . The HF of vegetable oil, also known as the polar fraction, contains most of the phenolic antioxidants, lignans and secoiridoids (Valavanidis et al., 2004). In our earlier work (Rękas et al., 2017), it was shown that the rapeseed oil of the Monolit variety contained 6 phenolic compounds, trans-sinapic acid, ferulic acid, $p$-coumaric acid, sinapine, sinapic acid methyl ester and canolol, where the latter accounted for as much as $90 \%$ of the total phenolics. The TEAC value of HF of the control oil was $0.67 \mathrm{mmol} / \mathrm{l}$. This was changed by seed microwaving prior to pressing. After $10 \mathrm{~min}$ of seed $\mathrm{MV}$, the antioxidant capacity of $\mathrm{HF}$ increased from to 0.84 to $5.83 \mathrm{mmol} \mathrm{TEAC} / 1$, for oil pressed from 2 and 10 min MV pre-treated seeds, respectively. A significant correlation between total phenolics and the antioxidant capacity in the rapeseed oil pressed from MV pre-treated seeds was obtained by Zheng et al., (2014). According to Oliviero et al., (2009) nut roasting increases oil hydrophilic antioxidant capacity due to Maillard browning reactions and/or the release of previously bound phenolic compounds (Talcott et al., 2005). Maillard rection products formed between carbohydrates and amino acids are very polar; whereas the Maillard type reaction products involving amino phospholipids like phosphatidylethanolamine (PE) are more lipophilic (Zamora et al., 2011). This would explain the potential role of the Maillard reaction products in protecting the tocopherols from thermal degradation during roasting or microwaving (McDaniel et al., 2012).

The LF of oils contains mostly tocopherols, triglycerides and phospholipids. The antioxidant capacity of LF results from the tocopherol concentration, in addition to their efficiency as antioxidants. $\delta$-T shows the highest antioxidant efficiency, followed by $\gamma-\mathrm{T} \approx \beta-\mathrm{T}$, whereas $\alpha$ - $\mathrm{T}$ is the least efficient antioxidant (Valavanidis et al., 2004). In this study, the control oil exhibited a TEAC value of $\mathrm{LF}$ of $1.58 \mathrm{mmol} \cdot \mathrm{L}^{-1}$. As $\mathrm{MV}$ time increased from 2 to $10 \mathrm{~min}$, the TEAC values of $\mathrm{LF}$ increased from 1.74 to $4.81 \mathrm{mmol} \cdot \mathrm{L}^{-1}$, respectively. Although carotenoids are known as highly lipophilic antioxidants, the concentration of these compounds in all the variants of oils studied did not exceed $1 \mathrm{mg} \cdot 100 \mathrm{~g}^{-1}$, and thus, their impact on the oil's antioxidant capacity of LF was much smaller when compared to the tocopherols. As pointed out by Shrestha et al., (2013), the increase in oil oxidative stability linked to the increase in tocopherol and lutein during seed roasting is insufficient to explain the increased oxidative stability 
TABLE 4. The effect of microwave pre-treatment of rapeseed on the changes in antioxidant capacities (mmol TEAC/l) of oil samples during 12 months of storage.

\begin{tabular}{|c|c|c|c|c|c|c|c|}
\hline \multirow[b]{2}{*}{ Oil fraction } & \multirow{2}{*}{$\begin{array}{l}\text { Storage Period } \\
\text { (months) }\end{array}$} & \multicolumn{6}{|c|}{ Microwave pre-treatment time (min) } \\
\hline & & $\mathbf{0}$ & 2 & 4 & 6 & 8 & 10 \\
\hline \multirow[t]{5}{*}{$\mathrm{HF}$} & 0 & $0.67 \pm 0.05^{\mathrm{d}}$ & $0.84 \pm 0.02^{c}$ & $0.93 \pm 0.05^{c}$ & $1.71 \pm 0.03^{\mathrm{d}}$ & $4.52 \pm 0.06^{d}$ & $5.83 \pm 0.04^{c}$ \\
\hline & 3 & $0.45 \pm 0.04^{c}$ & $0.72 \pm 0.06^{\mathrm{c}}$ & $0.81 \pm 0.02^{c}$ & $1.68 \pm 0.05^{\mathrm{d}}$ & $4.51 \pm 0.06^{\mathrm{d}}$ & $5.74 \pm 0.05^{c}$ \\
\hline & 6 & $0.32 \pm 0.02^{b}$ & $0.53 \pm 0.04^{b}$ & $0.69 \pm 0.03^{\mathrm{b}}$ & $1.55 \pm 0.06^{\mathrm{c}}$ & $4.39 \pm 0.04^{c}$ & $5.65 \pm 0.02^{b}$ \\
\hline & 9 & $0.26 \pm 0.03^{b}$ & $0.34 \pm 0.04^{\mathrm{a}}$ & $0.54 \pm 0.02^{\mathrm{a}}$ & $1.32 \pm 0.04^{b}$ & $4.18 \pm 0.04^{b}$ & $5.42 \pm 0.05^{\mathrm{b}}$ \\
\hline & 12 & $0.14 \pm 0.05^{\mathrm{a}}$ & $0.21 \pm 0.04^{\mathrm{a}}$ & $0.43 \pm 0.04^{\mathrm{a}}$ & $1.18 \pm 0.04^{\mathrm{a}}$ & $3.98 \pm 0.05^{\mathrm{a}}$ & $5.23 \pm 0.07^{\mathrm{a}}$ \\
\hline \multirow[t]{5}{*}{ LF } & 0 & $1.58 \pm 0.04^{c}$ & $1.74 \pm 0.02^{c}$ & $1.89 \pm 0.03^{\mathrm{d}}$ & $2.01 \pm 0.03^{d}$ & $2.05 \pm 0.04^{d}$ & $4.81 \pm 0.04^{d}$ \\
\hline & 3 & $1.42 \pm 0.04^{\mathrm{bc}}$ & $1.49 \pm 0.04^{b}$ & $1.56 \pm 0.07^{c}$ & $1.92 \pm 0.02^{\mathrm{c}}$ & $1.84 \pm 0.05^{\mathrm{c}}$ & $4.67 \pm 0.14^{c}$ \\
\hline & 6 & $1.38 \pm 0.02^{\mathrm{b}}$ & $1.48 \pm 0.04^{\mathrm{b}}$ & $1.52 \pm 0.03^{c}$ & $1.86 \pm 0.06^{c}$ & $1.73 \pm 0.04^{\mathrm{c}}$ & $4.41 \pm 0.02^{\mathrm{bc}}$ \\
\hline & 9 & $1.12 \pm 0.04^{\mathrm{a}}$ & $1.28 \pm 0.04^{\mathrm{a}}$ & $1.38 \pm 0.04^{\mathrm{b}}$ & $1.59 \pm 0.06^{\mathrm{b}}$ & $1.59 \pm 0.01^{\mathrm{b}}$ & $4.24 \pm 0.04^{b}$ \\
\hline & 12 & $0.93 \pm 0.34^{\mathrm{a}}$ & $1.12 \pm 0.04^{\mathrm{a}}$ & $1.22 \pm 0.08^{\mathrm{a}}$ & $1.34 \pm 0.05^{\mathrm{a}}$ & $1.39 \pm 0.06^{\mathrm{a}}$ & $4.11 \pm 0.06^{\mathrm{a}}$ \\
\hline \multirow[t]{5}{*}{$\mathrm{TF}$} & 0 & $2.33 \pm 0.11^{\mathrm{d}}$ & $2.63 \pm 0.95^{\mathrm{d}}$ & $3.07 \pm 0.94^{d}$ & $3.79 \pm 0.04^{c}$ & $6.77 \pm 0.03^{d}$ & $9.95 \pm 0.04^{\mathrm{e}}$ \\
\hline & 3 & $2.21 \pm 0.04^{d}$ & $2.58 \pm 0.14^{\mathrm{cd}}$ & $2.94 \pm 0.06^{d}$ & $3.66 \pm 0.09^{c}$ & $6.58 \pm 0.07^{\mathrm{cd}}$ & $9.74 \pm 0.05^{d}$ \\
\hline & 6 & $1.84 \pm 0.02^{c}$ & $2.42 \pm 0.07^{c}$ & $2.79 \pm 0.03^{\mathrm{b}}$ & $3.48 \pm 0.06^{\mathrm{b}}$ & $6.43 \pm 0.04^{c}$ & $9.57 \pm 0.12^{c}$ \\
\hline & 9 & $1.45 \pm 0.07^{\mathrm{b}}$ & $2.19 \pm 0.11^{b}$ & $2.57 \pm 0.04^{b}$ & $3.25 \pm 0.11^{b}$ & $6.21 \pm 0.03^{b}$ & $9.29 \pm 0.04^{b}$ \\
\hline & 12 & $1.24 \pm 0.06^{\mathrm{a}}$ & $1.68 \pm 0.08^{\mathrm{a}}$ & $2.11 \pm 0.02^{\mathrm{a}}$ & $2.88 \pm 0.06^{\mathrm{a}}$ & $5.96 \pm 0.06^{\mathrm{a}}$ & $9.01 \pm 0.04^{\mathrm{a}}$ \\
\hline
\end{tabular}

Antioxidant capacity of: hydrophilic fraction (HF); lipophilic fraction (LF) and oil (TF)

Means in a column (a-e across storage period) followed by the same letter are not significantly different $(p<0.05)$.

of oil. They concluded that phospholipids and its Maillard type browning reaction products together with the canolol formed during seed roasting were primarily responsible for the high oxidative stability of the roasted mustard seed oil samples. A marked increase in the oxidative stability of the oil with increasing phospholipid content in the range of 0 to $200 \mathrm{ppm}$ was also reported in a study of rapeseed (Prior et al., 1991) and pumpkin seed roasting (Vujasinovic et al., 2012). Phospholipids and its browning reaction products could show antioxidant activity by multiple mechanisms like chelating agent, emulsifier, hydrogen transfer, reducing agent, free radical scavenger, or peroxide breakdown (Zamora et al., 2011).

Storage of the control oil was found to significantly $(\mathrm{p}<0.05)$ decrease the antioxidant capacity of TF and the oil fractions (HF and LF). After 12 months of storage, the TEAC values of TF, HF and LF in the control oil decreased by 79.1, 41.1 and $46.8 \%$, respectively. A percentage decrease in antioxidant capacity was lower in the oils prepared from the MV pre-treated seeds when compare to the control oil. After 12 months of storage, the oil prepared from seed MV for 10 min lost approx. 10, 15 and $9 \%$ of its antioxidant capacity measured for HF, LF and TF, respectively. The reduction in the antioxidant capacity of TF of other oils obtained after seed MV for 2 to 8 min was within the range of $36.1-12.0 \%$, respectively. The rate of degradation of the antioxidant capacity of cold-pressed rapeseed oil versus oil produced from MV pre-treated rapeseed was examined by Zheng et al., (2014). It was concluded that approx. $80 \%$ and $40 \%$ of the antioxidant capacity of the untreated oil and oil pressed from MV pre-treated (7 min, $800 \mathrm{~W}$ ) seeds degraded during the 10 weeks of the autoxidation test at $60{ }^{\circ} \mathrm{C}$.

In order to explain the phenomena of antioxidant capacity changes, the data were fitted using kinetic models (Eq. 1). As shown in Table 5, a zero-order kinetic model adequately described the antioxidant capacity of the oil and its fractions. Although the degradation rate of antioxidant capacity of both hydrophilic and lipophilic oil fractions was similar in all the oil variants studied, the rate of TF degradation was lower in the oils pressed from MV pre-treated seeds than in the control oil. The respective $k$ value of TF calculated for the control oil was $9.1 \times 10^{-2} \mathrm{mmol}$ TEAC/l/month; whereas in oils pressed from seed MV for 2, 4, 6, 8 and 10 min, $k$ values were $(7.9,8.0,7.6,6.8,7.8) \times 10^{-2} \mathrm{mmol}$ TEAC/1/month, respectively.

\section{CONCLUSIONS}

Rapeseed microwave pre-treatment significantly affected the concentrations of lipophilic compounds in the oil. With longer seed exposure to MV, the level of $\alpha$-T in the oil was found to decrease; whereas the 
TABLE 5. Kinetic parameters from zero-order reaction kinetics for the antioxidant capacity degradation during the storage of rapeseed oils pressed from microwave-treated seeds.

\begin{tabular}{|c|c|c|c|c|c|c|c|}
\hline \multirow{2}{*}{\multicolumn{2}{|c|}{$\begin{array}{c}\text { Oil fraction } \\
\text { Kinetic parameter }\end{array}$}} & \multicolumn{2}{|c|}{ HF } & \multicolumn{2}{|c|}{ LF } & \multicolumn{2}{|c|}{ TF } \\
\hline & & $k \times 10^{-2}$ & $R^{2}$ & $k \times 10^{-2}$ & $R^{2}$ & $k \times 10^{-2}$ & $R^{2}$ \\
\hline \multirow{6}{*}{$\begin{array}{l}\text { Microwave pretreatment } \\
\text { time (min) }\end{array}$} & 0 & 4.4 & 0.9936 & 5.4 & 0.9569 & 9.1 & 0.9759 \\
\hline & 2 & 5.3 & 0.9534 & 5.2 & 0.9536 & 7.9 & 0.8766 \\
\hline & 4 & 4.2 & 0.9981 & 5.6 & 0.9231 & 8.0 & 0.9240 \\
\hline & 6 & 4.4 & 0.9463 & 5.6 & 0.9871 & 7.6 & 0.9595 \\
\hline & 8 & 4.5 & 0.9463 & 5.5 & 0.9891 & 6.8 & 0.9915 \\
\hline & 10 & 5.0 & 0.9590 & 5.8 & 0.9871 & 7.8 & 0.9898 \\
\hline
\end{tabular}

$k$ - kinetic rate constant (mmol TEAC/1/month); $R^{2}$ - coefficient of determination

amounts of $\gamma$-T and PC-8 increased with increasing MV time. Maximum lutein and $\beta$-carotene concentrations were obtained after 4 and 6 min of seed MV pre-treatment, respectively. Moreover, during microwaving, the thermal degradation of $\beta$-carotene took place, which led to the formation of 9-Z- and 13-Z- $\beta$-carotene. The kinetics of tocochromanol and carotenoid degradation during the storage of rapeseed oil pressed from MV pre-tretaed seeds followed a zero-order reaction. The application of seed MV pre-treatment prior to oil pressing slowed down the degradation rate of tocochromanols and carotenoids. The antioxidant capacity, as evaluated by using the 2,2-diphenyl-1-picrylhydrazyl radical, decreased following a zero-order kinetic. Although the degradation rate of the antioxidant capacity of both hydrophilic and lipophilic oil fractions was similar in all the oil variants studied, the rate of TF degradation was lower in the oils pressed from MV pre-treated seeds than in the control oil.

Abbreviations: HF: hydrophilic fraction; LF: lipophilic fraction; PC-8: plastochromanol-8; TF: antioxidant capacity of the oil, $\alpha-\mathbf{T}$ : alpha tocopherol; $\beta$-T: beta-tocopherol; $\gamma$-T: gamma-tocopherol; $\delta$-T: delta-tocopherol.

\section{REFERENCES}

Achir N, Pénicaud C, Avallone S, Bohuon P. 2011. Insight into $\beta$-Carotene Thermal Degradation in Oils with Multiresponse Modeling. J. Am. Oil Chem. Soc. 88, 20352045. https://doi.org/10.1007/s11746-011-1864-2

Achir N, Randrianatoandro VA, Bohuon P, Laffargue A, Sylvie Avallone S. 2010. Kinetic study of $\beta$-carotene and lutein degradation in oils during heat treatment. Eur. J. Lipid Sci. Technol. 112, 349-361. https://doi.org/10.1002/ ejlt.200900165

Anjum F, Anwar F, Jamil A, Iqbal M. 1999. Microwave roasting effects on the physico-chemical composition and oxidative stability of sunflower seed oil. J. Am. Oil Chem. Soc. 83, 777-784. https://doi.org/10.1007/s11746-006-5014-1

Cai L, Cao A, Aisikaer G, Ying T. 2013. Influence of kernel roasting on bioactive components and oxidative stability of pine nut oil. Eur. J. Lipid Sci. Technol. 115, 556-563. https://doi.org/10.1002/ejlt.201200337

Codex Stan. 2013. Codex Standard for Named Vegetable Oils. FAO/WHO, Rome, (Codex Stan 210-1999).
Choe E, Min DB. 2009. Mechanisms of Antioxidants in the Oxidation of Foods. Compr. Rev. Food Sci. Food Saf. 8, 345-358. https://doi.org/10.1111/j.1541-4337.2009.00085.x

Henry LK, Catignani GL, Schwartz SJ. 1998. Oxidative degradation kinetics of lycopene, lutein, and 9-cis and all-trans $\beta$-carotene J. Am. Oil Chem. Soc. 75, 823-829. https://doi. org/10.1007/s11746-998-0232-3

Krichene D, Salvador MD, Fregapane G. 2015. Stability of virgin olive oil phenolic compounds during long-term storage (18 months) at temperatures of $5-50{ }^{\circ} \mathrm{C}$. J. Agric. Food Chem. 63, 6779-6786. https://doi.org/10.1021/acs. jafc. 5 b02187

Lavelli V, Fregapane G, Salvador DM. 2006. Effect of storage on secoiridoid and tocopherol contents and antioxidant activity of monovarietal extra virgin olive oils. J. Agric. Food Chem. 54, 3002-3007. https://doi.org/10.1021/ jf0529181

Lee SW, Min KJ, Jeung MK, Park MH, Lee SY, Lee JH. 2010. Effects of roasting conditions of sesame seeds on the oxidative stability of pressed oil during thermal oxidation. Food Chem. 118, 681-685. https://doi.org/10.1016/j. foodchem.2009.05.040

Matthäus B. 2012. Effect of canolol on oxidation of edible oils, in Thiyam-Holländer U, Eskin NAM, Matthäus B. (Eds.) Canola and rapeseed: production, processing, food quality, and nutrition. Boca Raton, Taylor \& Francis, 317-332.

McDaniel KA, White BL, Dean LL, Sanders TH, Davis JP. 2012. Compositional and mechanical properties of peanuts roasted to equivalent colors using different time/ temperature combinations. J. Food Sci. 77, C1293-1299. https://doi.org/10.1111/j.1750-3841.2012.02979.x

Mezouari S, Eichner K. 2007. Comparative study on the stability of crude and refined rice bran oil during long-term storage at room temperature. J. Food Sci. Technol. 109, 198-205. https://doi.org/10.1002/ejlt.200600154

Moreau RA, Hicks KB, Powell MJ. 1999. Effects of heat pretreatment on the yield and composition of oil extracted from corn fiber. J. Agric. Food Chem. 47, 2867-2871. https://doi.org/10.1021/jf981186c

Oliviero T, Capuano E, Caemmerer B, Fogliano V. 2009. Influence of roasting on the antioxidant activity and $\mathrm{HMF}$ formation of a cocoa bean model systems. J. Agric. Food Chem. 57, 147-152. https://doi.org/10.1021/jf802250j

Pérez-Gálvez A, Mínguez-Mosquera MI. 2004. Degradation, under non-oxygen-mediated autooxidation, of carotenoid profile present in paprika oleoresins with lipid substrates of different fatty acid composition. J. Agric. Food Chem. 52, 632-637. https://doi.org/10.1021/jf0351063

Prior EM, Vadke VS, Sosulski FW. 1991. Effect of heat treatments on canola press oils. II. Oxidative stability. J. Am. Oil Chem. Soc. 68, 407-411. https://doi.org/10.1007/ BF02663757

Rękas A, Ścibisz I, Siger A, Wroniak M. 2017. The effect of microwave pretreatment of seeds on the stability and degradation kinetics of phenolic compounds in rapeseed oil 
during long-term storage. Food Chem. 222, 43-52. https:// doi.org/10.1016/j.foodchem.2016.12.003

Samaniego-Sánchez C, Oliveras-López MJ, Quesada-Granados JJ, Villalón-Mir M, López-G Serrana H. 2012. Alterations in picual extra virgin olive oils under different storage conditions. Eur. J. Lipid Sci. Tech. 114, 194-204. https://doi. org/10.1002/ejlt.201100191

Siger A, Kachlicki P, Czubinski J, Polcyn D, Dwiecki K, NogalaKałucka M. 2014. Isolation and purification of plastochromanol-8 for HPLC quantitative determinations. Eur. J. Lipid Sci. Tech. 116, 413-422. https://doi.org/10.1002/ ejlt.201300297

Siger A, Kaczmarek A, Rudzińska M. 2015. Antioxidant activity and phytochemicals content in cold-pressed rapeseed oil obtained from the roasting seeds. Eur. J. Lipid Sci. Tech. 117, 1225-1237. https://doi.org/10.1002/ ejlt.201400378

Siger A, Michalak M. 2016. The long-term storage of cold-pressed oil from roasted rapeseed: Effects on antioxidant activity and levels of canolol and tocopherols. Eur. J. Lipid Sci. Technol. 118, 1030-1041. https://doi.org/10.1002/ejlt.201500183

Shrestha K, Gemechu FG, De Meulenaer B. 2013. A novel insight on the high oxidative stability of roasted mustard seed oil in relation to phospholipid, Maillard type reaction products, tocopherol and canolol contents. Food Res. Int. 54, 587-594. https://doi.org/10.1016/j.foodres.2013.07.043

Talcott ST, Passeretti S, Duncan CE, Gorbet DW. 2005. Polyphenolic content and sensory properties of normal and high oleic acid peanuts. Food Chem. 90, 379-388. https://doi.org/10.1016/j.foodchem.2004.04.011

Tuberoso CIG, Kowalczyk A, Sarritzu E, Cabras P. 2007. Determination of antioxidant compounds and antioxidant activity in commercial oilseeds for food use. Food Chem. 103, 1494-1501. https://doi.org/10.1016/j. foodchem.2006.08.014

Wijesundera C, Ceccato C, Fagan P, Shen Z. 2008. Seed roasting improves the oxidative stability of canola (B. napus) and mustard (B. juncea) seed oils. Eur. J. Lipid Sci. Technol. 110, 360-367. https://doi.org/10.1002/ejlt.200700214

Wroniak M, Rekas A. 2016. Nutritional value of cold-pressed rapeseed oil during long term storage as influenced by the type of packaging material, exposure to light \& oxygen and storage temperature. J. Food Sci. Technol. 53, 1338-1347. https://doi.org/10.1007/s13197-015-2082-y

Vaidya B, Choe E. 2011a. Effects of seed roasting on tocopherols, carotenoids, and oxidation in mustard seed oil during heating. J. Am. Oil Chem. Soc. 88, 83-90. https://doi. org/10.1007/s11746-010-1656-0

Vaidya B, Choe E. 2011b. Stability of tocopherols and lutein in oil extracted from roasted or unroasted mustard seeds during the oil oxidation in the dark. Food Sci. Biotechnol. 20, 193-199. https://doi.org/10.1007/s10068-011-0026-5

Valavanidis A, Nisiotou C, Papageorgiou Y, Kremli I, Satravelas N, Zinieris N, Zygalaki H. 2004. Comparison of the radical scavenging potential of polar and lipidic fractions of olive oil and other vegetable oils under normal conditions and after thermal treatment. J. Agric. Food Chem. 52, 2358-2365. https://doi.org/10.1021/jf030491h

Vujasinovic V, Djilas S, Dimic E, Basic Z, Radocaj O. 2012. The effect of roasting on the chemical composition and oxidative stability of pumpkin oil. Eur. J. Lipid Sci. Technol. 114, 568-574. https://doi.org/10.1002/ejlt.201100158

Yoshida H, Takagi S, Mitsuhashi S. 1999. Tocopherol distribution and oxidative stability of oils prepared from the hypocotyls of soybeans roasted in microwave oven. $J$. Am. Oil Chem. Soc. 76, 915-920. https://doi.org/10.1007/ s11746-999-0106-3

Zamora R, León MM, Hidalgo FJ. 2011. Free radicalscavenging activity of nonenzymatically-browned phospholipids produced in the reaction between phosphatidylethanolamine and ribose in hydrophobic media. Food Chem. 124, 1490-1495. https://doi.org/10.1016/j. foodchem.2010.07.118

Zheng Ch, Yang M, Zhou Q, Liu Ch-S, Huang FH. 2014. Changes in the content of canolol and total phenolics, oxidative stability of rapeseed oil during accelerated storage. Eur. J. Lipid Sci. Technol. 116, 1675-1684. https://doi. org/10.1002/ejlt.201300229

Zeb A. 2012. Thermal degradation of $\beta$-carotene in food oils, in Preedy VR. (Ed.) Vitamin A and Carotenoids: Chemistry, Analysis, Function and Effects. Cambridge, Royal Society of Chemistry, 129-141. 